УДК 124.5

ГАЛИНА ДЬЯКОВСЬКА кандидат філософських наук, дочент кафедри філософії, сочіально-політичних і правових наук. ДВНЗ «Донбаський державний педагогічний університет»

(м. Слов'янськ, Україна) e-mail: dyakovskaya85@gmail.com,ORCID0000-0002-7558-9193

\title{
МІЖДИСЦИПЛІНАРНІ ПІДХОДИ ДО РОЗУМІННЯ «НОРМИ»
}

У статті досліджуються основні підходи до розуміння поняття «норми», актуальність дослідження останньої зумовив іiї універсальний характер. Встановлено, що різні сфери життєдіяльності індивіда мають свої методологічні підходи щодо розуміння норми. Автор визначає кількісно-статистичний і якісно-унітарний підходи як найбільш загальні щодо розуміння норми, де перший передбачає найбільшу частотність або повторюваність характеристик окремих елементів більшості, а другий - як те, що встановлене в якості оптимального в межах певної дискурсивної практики. У статті використовуються зазначені міждисциплінарні підходи до вивчення поняття «норма», що орієнтує на вивчення основних ознак та характеристик зазначеного поняття. В результаті аналізу було з'ясовано, що дихотомія підходів щодо норм приймається більшістю дослідників в тому чи іншому вигляді. Перший підхід статистичний, а тому постає динамічним і змінним, норма залежить від соціальних та інших змін. Другий підхід фіксує норму як універсалію або встановлений показник. У реальному житті зафіксовано взаємодію між двома розуміннями норми.

Ключові слова: норма; кількісно-статистичний підхід; якісно-унітарний підхід; філософський дискурс; спільнота.

Постановка завдання та аналіз останніх публікацій. Сучасний стан проблеми з'ясування поняття «норма» постає дискусійним через те, що наукова традиція по-різному використовує зазначене поняття. Особливо вимагає уваги розуміння його природи та сутності. Дослідження поняття «норма»є одним 3 актуальних і необхідних завдань сучасної філософії, від розумінні і вирішення яких залежать перспективи розвитку та функціонування індивіда i громадянського суспільства в цілому. Для аналізу такого феномену як «норма» виявилися доречними роботи Фуко М., в яких він показав, як змінювалося «норма» в системі освіти, пенітенціарній системі та в медицині (Фуко М., 2004), а також дослідження Филлипс Л., Йоргенсен М.В.

Тим не менш, у вітчизняній науці не був представлений комплексний соціально-філософський аналіз феномену норма.

Мета цього дослідження - дослідження міждисциплінарних підходів до розуміння поняття «норма» у соціально-філософському дискурсі.

Виклад основного матеріалу. Поняття «норма» виступає міждисциплінарним терміном, використовується в різних сферах нашого життя, має надзвичайну універсальність і придатність. «Дослідження норми у філософській теорії пізнання та лексичній семантиці дає підстави визнати іiі загально науковою категорією, у якій відображено найбільш спільні та істотні закони природи, суспільства та мислення», - таке визначення норми знаходимо у філософському словнику. (Философский словар, 2001, с. 237). 
«У сучасному науковому мисленні існує декілька підходів до тлумачення норми:

- статистичний підхід, згідно якому нормальність означає відповідність стандарту оцінки можливостей суб'єкта (наприклад, згідно шкали оцінки IQ, нормою є відповідність 85-114 балам, інші показники розглядаються як вищі або нижчі норми). Статистична норма $є$ відносною, оскільки вона соціокультурно зумовлена...

- адаптаційний підхід, який має на увазі нормальність як пристосованість, адаптованість. Але тут виникають проблеми із розумінням поняття адаптованості, оскільки психічні розлади, захворювання, відхилення також можна розглядати як приклад адаптації...

- психопатологічний підхід виходить із трактування норми як відсутності симптомів хвороби...

- культурно-релятивістський підхід вважає нормою - те, що відповідає баченню норми даної культури. У межах такого підходу виділяють два типи норми - загальну, яка відповідає стандартам усієї культурної групи, та рангова, якій мають відповідати особи з певним соціальним статусом.

- гуманістичний підхід розглядає норму саму по собі, не у зв’язаності 3 патологією...», зазначає дослідниця Скиртач В.М. у своїй монографії «Трансформація суб’єкта в клінічному дискурсі філософствування ХХ століття». (В.М. Скиртач, 2014, сс..196-197).

У різних сегментах життєдіяльності індивіда методологічні підходи визначення та розуміння норми як явища різняться фундаментальним чином. Виділяють два найбільш загальних підходи щодо розуміння норми: кількісностатистичний і якісно-унітарний.

Кількісно-статистичний підхід передбачає найбільшу частотність характеристик елементів більшості (соціальної групи, біологічного виду і т.д.), через це він передбачає обробку даних і встановлення найбільш поширених, властивих більшості елементів якостей для виявлення середньої статистичності, кількісної переваги. Такий підхід методологічно простий, тому універсальний для найширшого спектру наукової і прикладної діяльності, від таксономічної класифікації в природничій науці, до соціальних, політичних, психологічних опитувань в суспільно-гуманітарних дисциплінах, крім того для ефективного розподілу ресурсів в економіці і логістиці. В межах даного підходу нормою $\epsilon$ те, що притаманне більшості.

Якісно-унітарний підхід складніший, адже не передбачає єдиної практичної методології для обчислення норми, і полягає він у тому, що нормою вважається те, що встановлено як допустима межа для того, щоб в рамках певної дискурсивної практики можна було вважати оптимальним станом, це не припускає можливості ніяких деструктивних негативних наслідків, пов'язаних 3 втратою цього самого оптимального стану.

Такий тип норми приймається або встановлюється незалежно від кількісних статистичних даних, навпаки, він нав'язується в уніфікуючому обов’язковому порядку для всіх (в межах дискурсивної практики) і допускає, 
що більшість з властивими їй якостями може бути цілком собі ненормальною 3 позиції критерізації актуального підходу. Наприклад, якщо в якомусь середньовічному місті лютує епідемія холери, то зараженої може виявитися велика частина населення цього міста, однак статистичні дані ніяк не вплинуть на те, що за медичними стандартами нормою вважається, коли люди здорові, тобто не хворі, а в конкретній ситуації норма порушується навіть кількісно більшістю.

Зазначений підхід усвідомлюється як більш індивідуалістичний і працює не 3 кількісними вибірками для знаходження максимальної частоти та обчислення середньої статистичності, а встановлює універсальний ідеал, допустимий діапазон станів або строгий конкретний поріг, виходячи за який кожен окремий елемент буде вважатися ненормальним, навіть якщо такими виявляться всі елементи.

Резюмуючи опис другого підходу можна сказати, що відповідно останньому, нормою $\epsilon$ те, що в імперативному порядку встановлено як допустимий для кожного окремо, безвідносно до статистичних вибірок 3 їх найбільшою частотою ознак, що зустрічаються, і безвідносно до статистично усереднених показників.

Дана дихотомія підходів щодо норм найбільш загальна і корінна, в тому чи іншому вигляді (з незначними термінологічними відмінностями) вона формулюється всіма дослідниками норми. Перший підхід статистичний, тому в залежності від кількості, такий тип норми динамічний i мінливий, норма змінюється зі змінами всередині групи. В межах другого другому підходу норма являє собою строго встановлену універсалію, менш гнучку і гранично статичну, яка встановлюється для того, щоб оцінювати, взявши за основу певний показник, елементи групи, що змінюють свої якості, але сама норма не змінюється (або дуже повільно змінюється) з ними, і практично не залежить від статистичних змін всередині групи.

У підсумку ми робимо висновок, що нормою називається або те, що притаманне більшості, або те, що прийнято як допустиме в контексті будь-якої дискурсивної практики. Іноді «норма» в першому сенсі перетинається 3 нормою в другому сенсі, наприклад, в традиційних суспільствах гетеросексуальність $є$ нормою і в сенсі статистичної більшості, i в сенсі прийнятого поняття про соціальну допустимість. У реальному житті існують різні способи взаємодії між двома розуміннями норми, від повного консонансу, взаємного обумовлення i взаємного витікання один 3 одного, як у наведеному вище прикладі 3 гетеросексуальністю, до непримиренної конфронтації, як у випадку, наприклад, 3 брехнею. 3 самого раннього дитинства всім достеменно відомо, що брехня всіляко засуджується на рівні імперативного постулювання у соціальній та індивідуальної етиці, думка щодо брехні гранично консенсусна і однозначна, практично всі їі засуджують, проте практично всі і брешуть.

Наш соціальний простір подібно тканини витканий 3 ниток різних дискурсивних практик, які тісно переплетені, де вони перетинається одна 3 одною, вступають у конструктивну взаємодію і виходять одна з одної, або ж 
запалюється напруга, створюють протиріччя i непримиренність, а інші ж просто співіснують паралельно, дотримуються обопільного нейтралітету. Такими практиками ми можемо вважати окремі дискурси, що накладаються один на одного. Це можуть бути правила поводжень в інституційних організаціях, юридичні закони і кодекси, культові релігійні доктрини, наукові парадигми, різні мовні взаємодії, взаємодії медіапростору, корпоративні етики, субкультурні об’єднання, національні звичаї, культурні традиції локальних регіонів і т.д. 3 усього перерахованого вище і виткане те, що в нашій науковій традиції прийнято називати соціальною реальністю, яка має свої стандарти допустимості та прийнятності, які ми, в свою чергу, називаємо нормою.

Висновок. Отже, нами було виділено два основні підходи 3 дефініціями поняття «норма», де в одному випадку нормою є те, що притаманне більшості, а 3 іншого - норма це встановлений імперативним чином стандарт, 3 яким в індивідуальному порядку зобов'язаний слідувати кожен, щоб мати статус «нормального» 3 позиції конкретної дискурсивної практики для актуального окремо взятого випадку. Варто також відзначити що дихотомія «статистичного» і «стандартизованого» підходів стосується саме смислового розуміння того, що може матися на увазі під поняттям «норма», мова йде про семантичний аспект проблеми норми.

Підходи до розуміння смислів, що вкладаються у слово «норма»не є суто методологічним аспектом даної проблеми, хоч i мають в собі найбільш фундаментальні методологічні стратегії, проте ж, в кожній конкретній дискурсивної практиці існує величезна кількість власних специфічних методологій для встановлення норми в рамках того, що під нормою мається на увазі в конкретній практиці. Інакше кажучи, дихотомія фундаментального розуміння норми як статистичної більшості і як встановленого стандарту - це лише спосіб найбільш загального і широкого поділу підходів, притаманних всіляким специфічним методам, які існують у різних соціальних практиках, $\mathrm{i}$ повне редукування окремих методів в окремих практиках до одного чи іншого підходу було б необережністю через ігнорування індивідуальних дискурсивних особливостей розуміння норми у кожному конкретному випадку.

Загалом, в смисловому аспекті норми діляться на ті, які можна підраховувати, і на ті, які потрібно встановлювати, норми поділяються на ті, які задаються і на ті, які підраховуються, і з цього найбільш загального розподілу еклектичним чином складаються конкретні специфічні для окремих нормативних практик методи нормування. «Підрахунок найбільшої частотності для виявлення середини кривої розподілу» і «задавання правил, за якими буде виявлятися відповідність або невідповідність цим правилам» - ось найбільш релевантні, ясні, робочі та методологічно коректні критерії, які здійснюють дихотомію норми на два основні типи.

\section{СПИСОК ВИКОРИСТАНИХ ДЖЕРЕЛ}

Скиртач В.М. Трансформація суб'єкта в клінічному дискурсі філософствування XX століття: монографія [Текст] / Скиртач В.М. - Донецьк: ЛАНДОН-ХХІ, 2014. - 247c. 
Филлипс Л., Йоргенсен М.В. Дискурс-анализ. Теория и метод / Луиза Дж. Филлипс, Марианне В. Йоргенсен. - 2-е изд., испр. - Х.: Изд-во «Гуманитарный центр», 2008. $-352 \mathrm{c}$.

Фуко М. Психическая болезнь и личность / Фуко М.; [пер. с франц., предис. и ком-мент. О.А. Власовой]. - СПб.: Гуманитарная академия, 2009. - 320с.

Фуко М. Слова и вещи. Археология гуманитарных наук / Фуко М. - СПб.: А-cad, 1994. $406 \mathrm{c}$.

Философский словарь / под ред. И.Т. Фролова. - М.: Республика, 2001. - 719 с.

ГАЛИНА ДЬЯКОВСКАЯ кандидат философских наук, дочент кафедры философии, сочиильно-политических и правовых наук, Донбасский государственный педагогический университет

(2. Славянск, Украина) e-mail: dyakovskaya85@gmail.com,ORCID0000-0002-7558-9193

\section{МЕЖДИСЦИПЛИНАРНЫЕ ПОДХОДЫ К ПОНИМАНИЮ «НОРМЫ»}

В статье исследуются основные подходы к пониманию понятия «нормы», актуальность исследования последней обусловил ее универсальный характер. Установлено, что различные сферы жизнедеятельности индивида имеют свои методологические подходы к пониманию нормы. Автор определяет количественно-статистический и качественно-унитарный подходы как наиболее общие для понимания нормы, где первый предполагает наибольшую частотность или повторяемость характеристик отдельных элементов большинства, а второй как -то, что установлено в качестве оптимального в пределах определенной дискурсивной практики.В статье используются указанные междисциплинарные подходы к изучению понятия «норма», что ориентирует на изучение основных признаков и характеристик этого понятия. В результате анализа было установлено, что дихотомия подходов к норме принимается большинством исследователей в том или ином виде. Первый подход статистический, а поэтому является динамичным и переменным, норма зависит от социальных и других изменений. Второй подход фиксирует норму как универсалии или установленный показатель. В реальной жизни зафиксировано взаимодействие между двумя векторами понимания нормы.

Ключевые слова: норма; количественно-статистический подход; качественноунитарный подход; философский дискурс; сообщество

HALYNA DYAKOVSKA

PhD in Philosophy, Associate Professor, Department of Philosophy, Socio-Political and Legal Sciences, SHEI "Donbas State Pedagogical University" (Sloviansk, Ukraine) e-mail: dyakovskaya85@gmail.com,ORCID0000-0002-7558-9193

\section{INTERDISCIPLINARY APPROACHES TO UNDERSTANDING "NORM"}

The article examines the main approaches to understanding the concept of "norm", the relevance of the study is led to its universal nature. It has been established that various spheres of life activity of an individual have their own methodological approaches to understanding the concept of norm. The author defines quantitative-statistical and qualitative-unitary approaches as the most common for understanding the norm, where the first approach suggests the greatest frequency or repeatability of the characteristics of individual elements of the majority, and the second - as what is established as optimal within a certain discursive practice. The specified interdisciplinary approaches to the study of the concept of "norm" is used in the article, it focuses on the study of the main features and characteristics of this concept. As a result of the analysis, it was found that the dichotomy of 
approaches to the norm is accepted by the majority of researchers in one form or another. The first approach is statistical, and it is dynamic and variable, the norm depends on social and other changes. The second approach fixes the norm as universals or an established indicator. In real life, the interaction between the two vectors of understanding the norm is fixed. Setting a task and analyzing recent publications. The modern state of the problem of understanding the concept of "norm" is controversial because the scientific tradition uses this concept in different ways. Particularly requires attention to the understanding of its nature and essence. The study of the concept of "norm" is one of the urgent and necessary tasks of modern philosophy, the understanding and solution of which depend on the prospects of the development and functioning of the individual and civil society. For the analysis of such a phenomenon as a "norm", the work of Foucault M. were necessary. He showed the "norm" in the system of education, the penitentiary system and medicine. Presenting main material. The concept of "norm" acts as an interdisciplinary term, is used in various spheres of our lives, has an extremely versatile. The dichotomy of approaches to the norm is the most common and indigenous, in one form or another it is formulated by all researchers norm. The first approach is statistical, variable, the norm changes with the changes inside the group. The second approach considers the norm is a strictly universal, less flexible and extremely static one, which is established in order to evaluate, is based on a certain indicator, elements of the group that change their qualities, but the norm itself does not change. It does not depend on statistical changes inside the group. Our social space is like fabric woven from threads of various discursive practices that are closely interwoven, where they intersect with each other, enter into constructive interaction and come out of each other. These practices can be considered as separate discourses that are superimposed on each other. These may be rules of institutional organizations, legal laws and codes, religious doctrines, scientific paradigms, different language interactions, media space interactions, corporate ethics, subcultural associations, national customs, cultural traditions of local regions, etc. So, we find that in our scientific tradition we call social reality, which has its standards of admissibility and acceptability, which we call norm. Conclusions. The approaches to understanding the meanings of the word "norm" are not only methodological aspect of this problem, although they include the most fundamental methodological strategies, however, in each particular discursive practice there is a huge number of their own specific methodologies for setting the norm. In other words, the dichotomy of the fundamental understanding of the norm as a statistical majority and as a standard is only a way of the most general and broad division of approaches inherent in all kinds of specific methods that exist in different social practices, and the complete reduction of individual methods in particular practices to one or the other approach. It would be negligence because of ignoring the individual discursive features of understanding the norm in each particular case.

Key words: norm; quantitative and statistical approach, qualitative-unitary approach, philosophical discourse, community

\section{REFERENCES}

Skirtach V.M. (2009) Transformatsцiia subiekta v klinichnomu dyskursi filosofstvuvannia XX stolittia: monografiia [Teks]. Donetsk: LANDON-XXI, 2014. - 247s. (In Ukraine).

Fillips L., Yorgensen M.V. (2008) Dyskurs-analiz. Teoriia i metod / Luiza Dzh. Fillips, Marianne V. Yorgensen. - 2-e izd., ispr. - Kh.: Izd-vo «Gumanitarnyi tsentr». 352 s. (In Russian).

Fuko M. (2009) Psikhicheskaia bolezn i lichnos. Fuko M. [per. s frants., predis. i kom-ment. O.A. Vlasovoi]. - SPb.: Gumanitarnaia akademiia. 320s. (In Russian).

Fuko M. (1994). Slova i veshchi. Arkheologiia gumanitarnykh nauk / Fuko M. - SPb.: A-cad. 406 s. (In Russian).

Filosofskiy slovar (2001) [The philosophical dictionary]. Moscow, Respublika Publ. 719 s. (In Russian).

Надійшла до редакції 19.05.2019 